\title{
Influence of vitamin B auxotrophy on nitrogen metabolism in eukaryotic phytoplankton
}

Erin M. Bertrand and Andrew E. Allen*

Department of Microbial and Environmental Genomics, J. Craig Venter Institute, San Diego, CA, USA

Edited by:

Bess B. Ward, Princeton University, USA

\section{Reviewed by:}

Michael R. Twiss, Clarkson

University, USA

Kathleen Scott, University of South

Florida, USA

*Correspondence:

Andrew E. Allen, Department of

Microbial and Environmental

Genomic, J. Craig Venter Institute, 10355 Science Center Drive, San Diego, CA 92121, USA.

e-mail: aallen@jcvi.org

\begin{abstract}
While nitrogen availability is known to limit primary production in large parts of the ocean, vitamin starvation amongst eukaryotic phytoplankton is becoming increasingly recognized as an oceanographically relevant phenomenon. Cobalamin $\left(B_{12}\right)$ and thiamine $\left(B_{1}\right)$ auxotrophy are widespread throughout eukaryotic phytoplankton, with over $50 \%$ of cultured isolates requiring $B_{12}$ and $20 \%$ requiring $B_{1}$. The frequency of vitamin auxotrophy in harmful algal bloom species is even higher. Instances of colimitation between nitrogen and $\mathrm{B}$ vitamins have been observed in marine environments, and interactions between these nutrients have been shown to impact phytoplankton species composition. This review surveys available data, including relevant gene expression patterns, to evaluate the potential for interactive effects of nitrogen and vitamin $B_{12}$ and $B_{1}$ starvation in eukaryotic phytoplankton. $\mathrm{B}_{12}$ plays essential roles in amino acid and one-carbon metabolism, while $B_{1}$ is important for primary carbohydrate and amino acid metabolism and likely useful as an anti-oxidant. Here we will focus on three potential metabolic interconnections between vitamin, nitrogen, and sulfur metabolism that may have ramifications for the role of vitamin and nitrogen scarcities in driving ocean productivity and species composition. These include: (1) $B_{12}, B_{1}$, and $N$ starvation impacts on osmolyte and antioxidant production, (2) $B_{12}$ and $B_{1}$ starvation impacts on polyamine biosynthesis, and (3) influence of $B_{12}$ and $B_{1}$ starvation on the diatom urea cycle and amino acid recycling through impacts on the citric acid cycle. We evaluate evidence for these interconnections and identify oceanographic contexts in which each may impact rates of primary production and phytoplankton community composition. Major implications include that $\mathrm{B}_{12}$ and $\mathrm{B}_{1}$ deprivation may impair the ability of phytoplankton to recover from nitrogen starvation and that changes in vitamin and nitrogen availability may synergistically impact harmful algal bloom formation.
\end{abstract}

Keywords: cobalamin, thiamine, S-adenosylmethionine, nitrogen, sulfur, urea cycle, microbial interactions, harmful algal blooms

\section{INTRODUCTION}

The rate, magnitude, and species composition of marine primary production has a profound influence of global carbon cycling and therefore climate. As a result, factors controlling the growth of marine primary producers are of considerable interest. While nitrogen and iron availability are often considered the primary bottom-up controls on short-term marine primary productivity, the importance of organic growth factors received considerable early attention (Cowey, 1956; Droop, 1957, 1962; Menzel and Spaeth, 1962; Provasoli, 1963; Gold, 1968; Carlucci and Silbernagel, 1969; Carlucci and Bowes, 1970; Swift and Taylor, 1972; Swift, 1981) and is the subject of renewed interest (e.g., Sañudo-Wilhelmy et al., 2012).

Recent developments in analytical techniques (Okbamichael and Sañudo-Wilhelmy, 2004; Sañudo-Wilhelmy et al., 2012), application of trace metal clean bioassay experiments (Panzeca et al., 2006; Sañudo-Wilhelmy et al., 2006; Bertrand et al., 2007; Gobler et al., 2007; Koch et al., 2011), and culture-based surveys of vitamin requirements (Croft et al., 2005; Tang et al.,
2010) have identified $B_{12}$ (cobalamin) and $B_{1}$ (thiamine) as highly important growth factors for eukaryotic phytoplankton and suggest that these micronutrients have the potential to broadly influence marine productivity and species composition. Due to the fact that $B_{12}$ and $B_{1}$ both play numerous essential roles in cellular biochemistry, starvation for these nutrients has the potential to impact phytoplankton cellular metabolism through a range of mechanisms. The increase in available genome and transcriptome data for relevant organisms has opened doors for new modes of inquiry into the role of these micronutrients in phytoplankton metabolism as well as their potential for interaction with additional states of nutrient deprivation (Croft et al., 2006; Helliwell et al., 2011; Bertrand et al., 2012). Here we review available data to examine potential interactions between $B_{12}, B_{1}$, and nitrogen deprivation and sulfur metabolism in eukaryotic phytoplankton communities and provide insight into the potential implications of these interactions for phytoplankton evolutionary trajectories and biogeochemical cycling. 


\section{COBALAMIN AND THIAMINE PRODUCTION, DEMAND, AND BIOCHEMICAL FUNCTION}

Cobalamin, $\mathrm{B}_{12}$, is a cobalt-containing organometallic micronutrient that conducts elegant chemistry facilitated by the controlled reactivity of the axial Co-C bond in methyl and adenosylcobalamin (Schrauzer and Deutsch, 1969; Lexa and Savant, 1983; Drennan et al., 1994). The resulting reactivity provides the biochemical capacity for methylation and rearrangement reactions, where a hydrogen atom on one carbon constituent is exchanged for another functional group, typically a methyl, amine, or alcohol group. Cobalamin is believed to be produced only by select bacteria and archaea (Roth et al., 1996; Martens et al., 2002) and is required by humans and other metazoans, by an estimated half of all eukaryotic phytoplankton (Tang et al., 2010) and by some bacteria that are not able to synthesize it (Rodionov et al., 2003; Zhang et al., 2009). Vitamin $B_{12}$ biosynthesis requires over 30 enzymatic steps and significant consumption of cellular energy, carbon, nitrogen, cobalt, zinc, and in some cases iron (Roth et al., 1996; Raux et al., 2000).

Vitamin $\mathrm{B}_{12}$ demand by eukaryotic phytoplankton is thought to arise from its role as a cofactor in the enzyme methionine synthase, which catalyzes the conversion of homocysteine and methyl-tetrahydrofolate to tetrahydrofolate and methionine (Table 1 ). The active form of $\mathrm{B}_{12}$ in methionine synthase is methylcobalamin. Algae that require $B_{12}$ absolutely posses only the $\mathrm{B}_{12}$-dependant version of this enzyme (MetH), while those that do not have an absolute requirement have the ability to use an alternative $B_{12}$ independent version (MetE) (Croft et al., 2005). Phylogenetic analysis of metE and metH coding sequences support a complex evolutionary history of metE gene gain and loss within eukaryotic organisms. In contrast, the phylogeny of $m e t H$ is well resolved and apparently monophyletic in eukaryotes (Helliwell et al., 2011). These analyses suggest that absolute $B_{12}$ requirements in eukaryotic algae have likely arisen as a result of multiple independent loses and acquisitions of metE from eukaryotic genomes. Indeed, under high $\mathrm{B}_{12}$ concentrations, metH is continually expressed by algal strains, whereas $m e t E$, if present, is repressed until $\mathrm{B}_{12}$ is depleted (Croft et al., 2005; Helliwell et al., 2011; Bertrand et al., 2012). These results suggest that $B_{12}$ auxotrophy in eukaryotic algae arose as a function of variable $B_{12}$ availability in the environment. This is supported by observations that the distribution of metE in eukaryotic phytoplankton does not follow phylogenetic lines. Importantly, there is strain level variability in whether or not phytoplankton exhibit an absolute requirement for $\mathrm{B}_{12}$ (Tang et al., 2010). In addition, $\mathrm{B}_{12}$ is a cofactor in the enzyme methylmalonyl coA mutase $(\mathrm{mmcM})$, which is encoded in some but not all $\mathrm{B}_{12}$ requiring phytoplankton genomes (Table 1). mmcM's function in eukaryotic phytoplankton remains somewhat unclear, though it likely plays a role in the citric acid cycle as well as fatty acid and propionate metabolism. However, the presence of $\mathrm{mmcM}$ genes in phytoplankton genomes does not confer a $\mathrm{B}_{12}$ requirement under typical laboratory growth conditions (Croft et al., 2006).

Thiamine, $\mathrm{B}_{1}$, is a cofactor required by all organisms and produced by many prokaryotes as well as by fungi, plants, and some eukaryotic phytoplankton (Webb et al., 2007). It is a sulfur-containing compound, produced though joining of a pyrimidine and a thiazole moiety, and is phosphorylated in its coenzyme form (thiamine diphosphate). In bacterial biosynthetic pathways, thiazole biosynthesis requires six distinct enzymatic steps and pyrimidine synthesis requires two (Rodionov et al., 2002; Jurgenson et al., 2009). While the bacterial thiamine biosynthesis pathway is well characterized, eukaryotic biosynthesis pathways remain poorly understood and appear to be distinct in plants and fungi (Jurgenson et al., 2009). Algal thiamine biosynthesis is even less well-characterized but likely conducted by some enzymes similar to bacterial thiamine biosynthesis genes and some enzymes similar to the yeast and plant pathways (Croft et al., 2006), though this remains to be conclusively demonstrated.

While thiamine was one of the first organic cofactors identified as important for algal growth, early work showed that there are some phytoplankton strains that produce thiamine de novo, and some that can scavenge and salvage either the thiazole or pyrimidine moieties from the environment in order to construct a functional cofactor (Droop, 1958; Provasoli and Carlucci, 1974). Preliminary inquiry into eukaryotic phytoplankton genomes conducted via identification of coding sequences similar to those encoding known bacterial, fungi, and plant thiamine biosynthesis enzymes suggests that there are potentially different pathways for thiamine production in stramenopiles versus the green algal lineage (Table 2, McRose et al., 2012). The absence of a gene encoding $\mathrm{ThiC}$, a protein involved in pyrimidine biosynthesis, appears to correlate with $B_{1}$ auxotrophy in algae with sequenced genomes, regardless of lineage (Table 2 ). This intriguing observation warrants further exploration. Since ThiC is involved in pyrimidine biosynthesis, the relationship between ThiC gene presence and thiamine auxotrophy is likely to hold only for auxotrophs with the ability to synthesize thiamine diphosphate when provided the pyrimidine moiety, not those that can synthesize the vitamin when provided with the thiazole moiety, such as some dinoflagellates and cryptophytes (Droop, 1958). ThiC is an interesting protein; it requires $\mathrm{S}$-adenosyl methionine (SAM) for activity (Chatterjee et al., 2008), is an iron-sulfur cluster protein, and is present in both the plant and bacterial thiamine biosynthesis pathways (Goyer, 2010).

Thiamine catalyzes a number of transformations that are important in carbohydrate and branched amino acid metabolism including those involved in glycolysis, the pentose phosphate pathway, and the tricarboxylic acid pathway. These notably include 2-oxoglutarate dehydrogenase (ODG), pyruvate dehydrogenase/decarboxylase, branched-chain $\alpha$-ketoacid dehydrogenase, as well as transketolases, acetolactate synthase, and alpha-keto acid dehydrogenase. The chemistry involved in these reactions often includes two carbon group transfers or dehydrogenation reactions (Frank et al., 2007). There is mounting evidence that thiamine may play additional, non-cofactor roles as well. In plants, thiamine has been tied to cellular responses to oxidative stress and disease. Plants subjected to hydrogen peroxide, salt stress, and high light stress, for example, all showed enhanced thiamine production and increased thiamine biosynthesis protein transcripts, such as ThiC (reviewed in Goyer, 2010; Rapala-Kozik et al., 2012). It is possible that this increase 


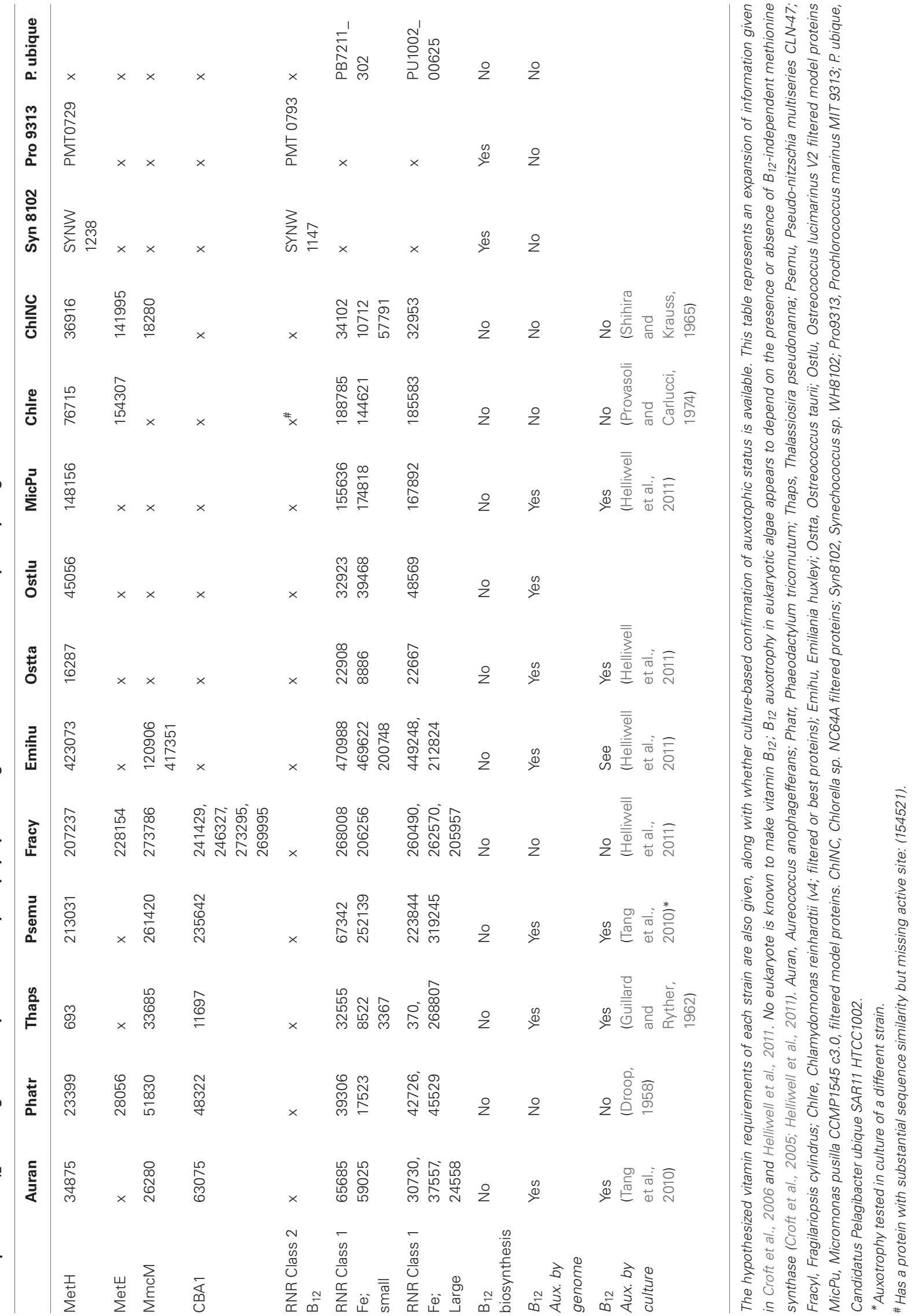




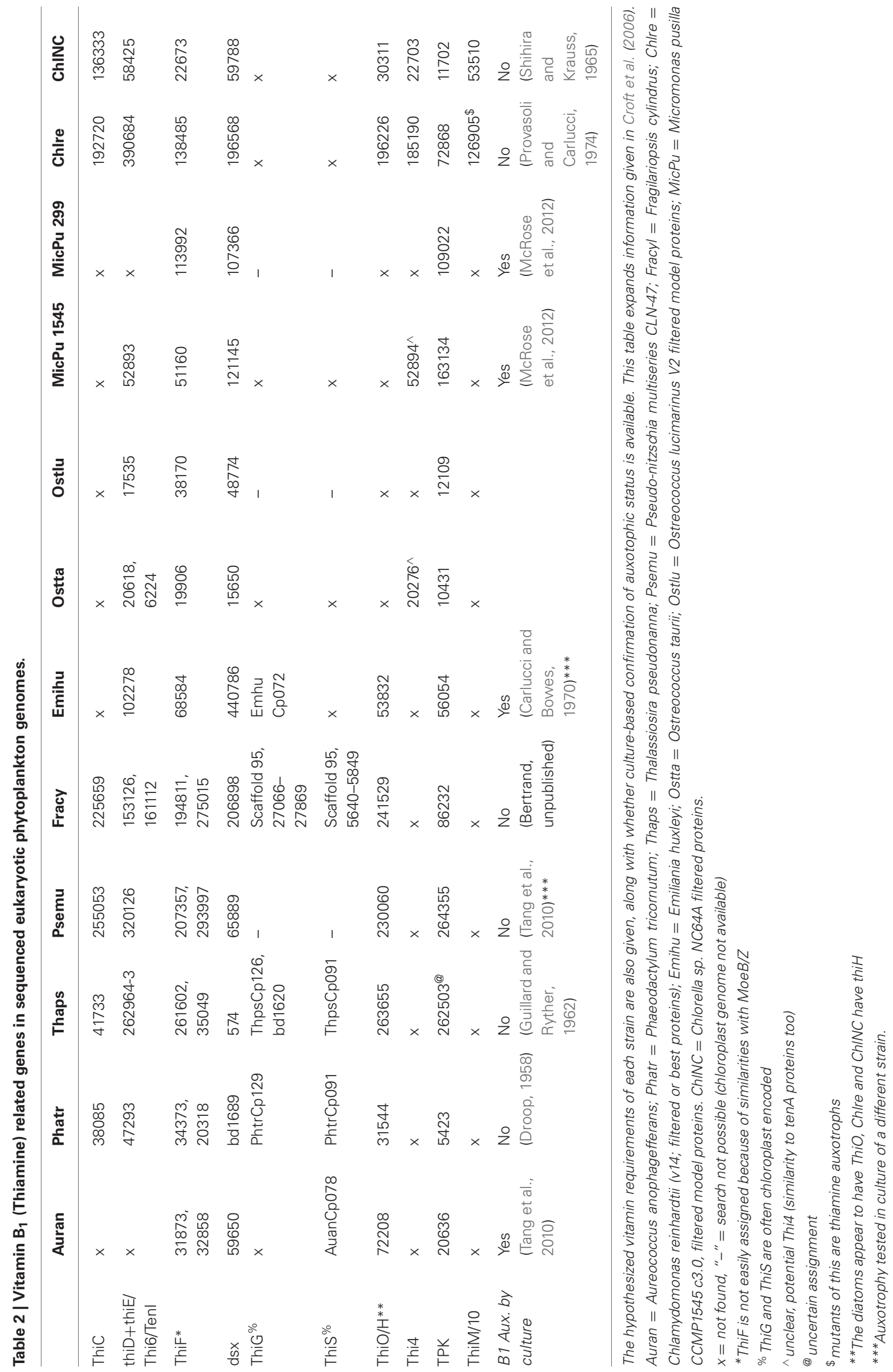


in thiamine under stress results from demand for transketolase activity in the pentose phosphate pathway which regenerates NADPH required for activity of some antioxidants (Goyer, 2010). However it is also possible that thiamine itself functions as an antioxidant in these cells, as thiamine compounds have antioxidant capacities, likely through the transfer of $\mathrm{H}+$ from amino groups on the thiazole and pyrimidine rings to reactive species (Hu et al., 1995; Lukienko et al., 2000; Bettendorff and Wins, 2009). While there has been comparatively little study of these potential roles of thiamine in algae, available evidence suggests that thiamine biosynthesis per cell in diatoms increases as a function of increasing cell density and nutrient depletion, which may be caused by the increase in oxidative stress (Pinto et al., 2003).

Thiamine auxotrophy is strikingly different from $\mathrm{B}_{12}$ auxotrophy in algae; while $\mathrm{B}_{12}$ requirements are determined by the ability of a phytoplankton strain to replace $\mathrm{B}_{12}$-requiring metabolisms (Table 1), $\mathrm{B}_{1}$ auxotrophy is defined by whether or not an algal strain is able to synthesize the vitamin de novo (Table 2). Considering that the enzymes for $\mathrm{B}_{1}$ biosynthesis are not yet completely elucidated in algae, it is difficult to discern, through analysis of protein coding sequences, the evolutionary origin of $\mathrm{B}_{1}$ auxotrophy. However, observations concerning the phylogenetic distribution of thiamine auxotrophy support the notion that biosynthesis potential may have also been lost and acquired multiple times. For instance, in the case of two strains of the same species of dinoflagellate, isolated from the same site, one is a $B_{1}$ auxotroph and one is not (Tang et al., 2010). Among Micromonas spp. strains with thiamine requirements, one is missing more of the biosynthetic pathway than the other (McRose et al., 2012; Table 2). These data suggests that like $\mathrm{B}_{12}, \mathrm{~B}_{1}$ auxotrophy in algae has likely arisen numerous times though gene loss events. Such loss events could be driven by chronically high thiamine availability coupled to transcriptional repression and associated loss of purifying selection and gene erosion. While this repression is yet to be documented, eukaryotic phytoplankton genomes encode thiamine riboswitches (Croft et al., 2007; Worden et al., 2009); which offer a mechanism by which high thiamine bioavailability can regulate gene transcription.

\section{OCEANOGRAPHIC DISTRIBUTIONS AND CYCLING}

In the ocean, dissolved $(0.2 \mu \mathrm{m})$ vitamin $B_{12}$ and $B_{1}$ show variable but often nutrient-like depth profiles and are thought to be present in sub-picomolar quantities to up to $30 \mathrm{pM}$ for $\mathrm{B}_{12}$ and $500 \mathrm{pM}$ for $\mathrm{B}_{1}$ (Sañudo-Wilhelmy et al., 2012). Concentrations of these vitamins in coastal waters are generally higher than in open ocean regions (Panzeca et al., 2009). Measurement techniques for B vitamins in seawater remained restricted to bioassays (Menzel and Spaeth, 1962; Carlucci, 1966) until solid phase extraction, high pressure liquid chromatography methods were developed (Okbamichael and Sañudo-Wilhelmy, 2004; Okbamichael and Sanudo-Wilhelmy, 2005). Development of these techniques, coupled with mass spectrometry, has fostered more efficient and accurate methods for vitamin detection and quantitation in seawater. Such methods however still require inconveniently large volumes and are not currently optimized to detect $B_{12}$ with different $\alpha$ or $\beta$ axial groups or differentially phosphorylated forms of thiamine, which may be present in seawater and could be important for bioactivity as well as biogeochemical cycling. In addition, concentration measurements alone may not be an informative measure of the impact of vitamins on marine biogeochemical processes since their concentrations are low and they may be cycled and regenerated rapidly in the euphotic zone as a function of biological production and consumption as well as abiotic processing. The halflife of $\mathrm{B}_{12}$ in the surface ocean with respect to photodegradation alone is approximately 4 days, while $B_{1}$ is more resistant to abiotic transformations in seawater (Gold et al., 1966; Carlucci et al., 1969). This, along with differences in production and consumption of vitamins by different components of marine microbial communities, may explain the observation that $\mathrm{B}_{12}$ and $\mathrm{B}_{1}$ concentrations and cycling may be decoupled in the water column (Panzeca et al., 2008; Sañudo-Wilhelmy et al., 2012). It remains a challenge to reconcile the interesting observation that B vitamin abundance patterns are associated with basinscale water mass origin (Sañudo-Wilhelmy et al., 2012) with the likely rapid changes in production and consumption of these vitamins. To address this question, continued efforts to measure these vitamins, along with assessments of microbial community composition and vitamin acquisition rates, should include assessments of variability on short (hours to days) as well as seasonal timescales.

Either through dissolved organic matter exudation and cell lysis via the cycling of the microbial loop, (Azam, 1998; Karl, 2002; Droop, 2007) or through direct symbiotic interaction (Croft et al., 2005), some portion of the bacterial and archaeal community must be the ultimate source of vitamin $B_{12}$ to eukaryotic phytoplankton. The genetic potential for vitamin $\mathrm{B}_{12}$ production remains largely uncharacterized in any marine environment (Bertrand et al., 2011a). This is in part because the occurrence of the biosynthesis pathway among bacterial and archaeal lineages is extremely variable and is not easily queried using typical phylogenetic profiling techniques. An exception to this is the marine cyanobacteria, where all sequenced genomes appear to contain the $\mathrm{B}_{12}$ biosynthetic pathway (Rodionov et al., 2003), and numerous strains have been shown to produce significant amounts of $B_{12}$ (Bonnet et al., 2010). The identity of other groups that contribute significantly to oceanic $B_{12}$ production remains unclear, however, and is of particular importance in regions with scarce cyanobacterial populations such as the polar oceans (Caron et al., 2000; Marchant, 2005). The extremely abundant SAR11 group appears to neither synthesize nor require the vitamin (Table 1). In addition, there are examples from many sequenced marine bacterioplankton genomes of strains that either cannot produce the vitamin themselves but require it for various metabolisms, or those that can salvage degraded $\mathrm{B}_{12}$ for repair and reuse (Bertrand et al., 2011a). In sum, $\mathrm{B}_{12}$ uptake by marine bacteria and archaea can be as significant as uptake by eukaryotic phytoplankton (Bertrand et al., 2007; Koch et al., 2011). This results in a scenario in which eukaryotic phytoplankton likely compete for $\mathrm{B}_{12}$ resources with some components of the prokaryotic community (Bertrand et al., 2011b; Sañudo-Wilhelmy et al., 2012). 
Thiamine sources to eukaryotic phytoplankton include de novo production, uptake or salvage from bacterial production, or uptake and salvage of thiamine produced by other algae (Carlucci and Bowes, 1970; Provasoli and Carlucci, 1974). Similar to $\mathrm{B}_{12}$, competition likely occurs for $\mathrm{B}_{1}$ amongst microalgae as well as between algal and bacterial groups since not all prokaryotes have the ability to produce thiamine (Rodionov et al., 2002). It remains unclear, however, what the relative importance of these uptake vectors are and how this varies across oceanic regions. A striking difference between $B_{12}$ and $B_{1}$ auxotropy is that $B_{1}$ requirements in algae could potentially be supplied by growth with $\mathrm{B}_{1}$ producing algal strains as well as with some bacteria (Table 2). This is in contrast to $B_{12}$ where the only potential source of $\mathrm{B}_{12}$ to auxotrophic algae is bacterial and archaeal production. This opens interesting avenues for exploration of species succession and potential commensalism between not only algae and bacteria but also between different algal strains.

Bottle incubation bioassay experiments have suggested that availability of $B_{12}$ and to some degree $B_{1}$ influence overall rates of primary production as well as phytoplankton community composition in regions ranging from the Southern Ocean to temperate coastal environments (Panzeca et al., 2006; SañudoWilhelmy et al., 2006; Bertrand et al., 2007; Gobler et al., 2007; Koch et al., 2011). In many cases, addition of B vitamins to communities resulted in the proliferation of diatoms or dinoflagellates and larger groups of eukaryotic phytoplankton (Table 3). This may have important implications for carbon and nitrogen export as well as silica cycling, since larger phytoplankton tend to support a higher percentage of organic matter export. In addition, coastal and open ocean North Atlantic studies revealed that regions with higher $\mathrm{B}_{12}$ concentrations correlated with regions with high bacterioplankton productivity or density (Gobler et al., 2007; Panzeca et al., 2008), though it remains unclear whether these correlations are due to bacterial production of the vitamin or enhanced bacterial abundance as a result of higher $\mathrm{B}_{12}$ availability. In the Ross Sea of the Southern Ocean, bacterial abundance was shown to be low where primary production was stimulated by $\mathrm{B}_{12}$, meaning that where bacterioplankton communities were more numerous, $\mathrm{B}_{12}$ was less likely to limit primary production (Bertrand et al., 2011b). This suggests that bacterioplankton have an important impact on $\mathrm{B}_{12}$ supply to eukaryotic phytoplankton, at least in polar regions. However, intimate associations between bacteria and eukaryotic phytoplankton are known to occur (Figure 1; Cole, 1982; Grossart et al., 2005); the importance of these associations to B vitamin cycling and availability to phytoplankton in the marine environment are just beginning to be explored and offer numerous exciting avenues for continued research.

\section{THE IMPORTANCE OF NITROGEN TO EUKARYOTIC PHYTOPLANKTON}

Nitrogen is an essential component of all life. The availability of nitrogen is thought to limit the productivity of marine microbial communities in large portions of the ocean (McCarthy and Carpenter, 1983; Hecky and Killam, 1988; Moore et al., 2004). Oceanic dissolved nitrogen distributions are driven in

Table 3 | Results of B-vitamin supplementation in published marine bottle incubation bioassays.

\begin{tabular}{|c|c|c|c|c|c|c|}
\hline Location & $\begin{array}{l}\text { Experiments with } \\
\text { stimulation of Chl } \\
\text { a production by a } \\
\text { B vitamin }\end{array}$ & $\begin{array}{l}\text { B vitamin } \\
\text { changed } \\
\text { community } \\
\text { composition? }\end{array}$ & $\begin{array}{l}\text { Size class or } \\
\text { functional } \\
\text { group with } \\
\text { biggest } \\
\text { response }\end{array}$ & Notes & $\begin{array}{l}\text { Interactions } \\
\text { with } \mathrm{N}\end{array}$ & References \\
\hline $\begin{array}{l}\text { Long Island } \\
\text { embayments }\end{array}$ & $1 / 1$ & $1 / 1$ & $>5 \mu \mathrm{m}$ & $\begin{array}{l}\text { Observed correlation } \\
\text { between dissolved } \\
\mathrm{B}_{12}, \mathrm{~B}_{12} \text { drawdown } \\
\text { and growth of large } \\
\text { phytoplankton }\end{array}$ & Yes & $\begin{array}{l}\text { Sañudo-Wilhelmy } \\
\text { et al., } 2006\end{array}$ \\
\hline Antarctic Peninsula & $1 / 1$ & $1 / 1$ & nd & $\begin{array}{l}\text { Primary and } \\
\text { secondary limitation } \\
\text { by } \mathrm{B}_{1}+\mathrm{B}_{12}\end{array}$ & nd & $\begin{array}{l}\text { Panzeca et al., } \\
2006\end{array}$ \\
\hline Ross Sea & $2 / 3$ & $3 / 3$ & Diatoms & - & nd & $\begin{array}{l}\text { Bertrand et al., } \\
2007\end{array}$ \\
\hline $\begin{array}{l}\text { Long Island } \\
\text { embayments }\end{array}$ & $4 / 14$ & - & $>5 \mu \mathrm{m}$ & $\begin{array}{l}\text { Fall experiments: } \\
\text { large size fraction B } \\
\text { vitamin limited }\end{array}$ & Yes & $\begin{array}{l}\text { Gobler et al., } \\
2007\end{array}$ \\
\hline Ross Sea & $2 / 5$ & $5 / 5$ & Diatoms & $\begin{array}{l}\mathrm{B}_{12} \text { uptake rates } \mathrm{Fe} \\
\text { limited }\end{array}$ & nd & $\begin{array}{l}\text { Bertrand et al., } \\
2011 a, b\end{array}$ \\
\hline Gulf of Alaska & $1 / 2$ & $2 / 2$ & $\begin{array}{l}\text { Dinoglagellates in } \\
\text { coastal, diatoms in } \\
\text { upwelling }\end{array}$ & $\begin{array}{l}\mathrm{N} \text { and } \mathrm{Fe} \\
\text { co-limitation with } \mathrm{B}_{12}\end{array}$ & Yes & Koch et al., 2011 \\
\hline
\end{tabular}

nd $=$ no data 


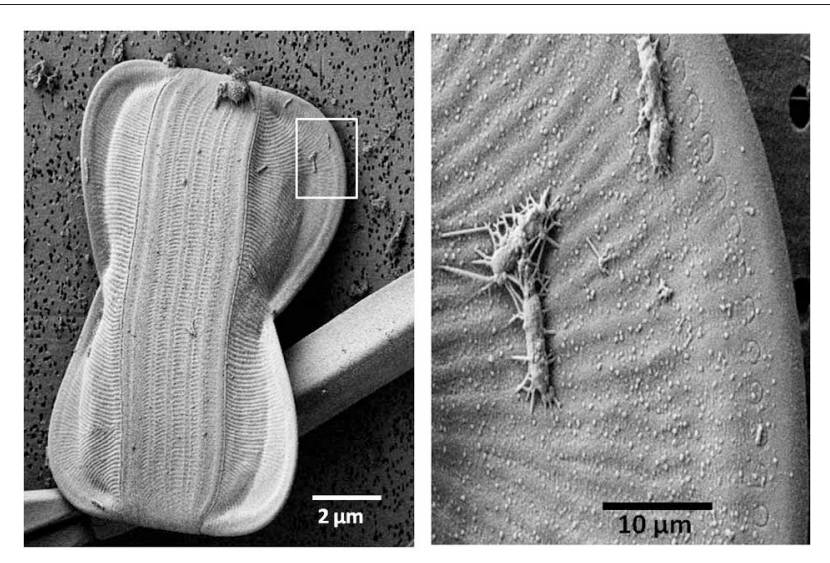

FIGURE 1 | Bacteria can be intimately associated with diatoms. This sea ice Amphiprora diatom cell has bacterial cells attached through an apparently tight association likely via the use extracellular polymeric substances (EPS). SEM micrographs were collected at the UC Riverside Center for Nanoscale Science and Engineering. Samples were filtered critical point dried to preserve cellular structures, coated with Pt:Pd to prevent charging, and imaged at $2 \mathrm{kv}$ on a Zeiss $1540 \mathrm{FE}-\mathrm{SEM}$

large part by coupled biological processing and large scale patterns in ocean circulation. Dissolved inorganic nitrogen (DIN) is generally considered to be the major source of nitrogen to marine microbial communities; the availability of these compounds (nitrate, nitrite, and ammonia), particularly in the oligotrophic ocean, can be depleted below $0.03 \mu \mathrm{M}$ (Capone, 2000). Phytoplankton growth limitation by inorganic nitrogen availability has also been observed in coastal and upwelling environments (Kudela and Dugdale, 2000). The availability of this inorganic nitrogen has long been used, via nitrogen balancing calculations, to estimate organic matter export from the surface ocean (Eppley and Peterson, 1979), a concept which has profoundly influenced the field of biogeochemical oceanography. Models of the role of different nitrogen sources to phytoplankton and their microbial transformations have evolved to include additional processes, yet this conceptualization of balance between dissolve nitrate upwelled into the euphotic zone and export of biogenic and dissolved organic nitrogen (Bronk et al., 1994) continues to shape our understanding of controls on marine primary production and carbon cycling.

The relative availability of different $\mathrm{N}$ sources is now known to play a role in structuring phytoplankton species composition. Though reduced $\mathrm{N}$ compounds require less energy to assimilate, there are differences between taxonomic groups in terms of the impact of these differences on growth rate and the impact of ammonia availability on oxidized $\mathrm{N}$ acquisition (Dortch, 1990). In addition, differences in the ability of varying phytoplankton functional groups to respond to variable nitrogen concentrations and sources can create important niche dimensions. For instance, diatoms are a particularly successful group of eukaryotic phytoplankton that tend to dominate in coastal and upwelling regions. These locations are often characterized by highly variable nitrogen sources and concentrations. The ability of diatoms to respond quickly to pulsed nitrogen additions can, in part, explain a portion of their success in such environments. Their successful responses to these pulsed additions are partially explained by their ability to tightly couple anabolic and catabolic nitrogen transformations through incorporation of a complete urea cycle into central metabolism (Allen et al., 2011). Diatoms also tend to exhibit their maximal growth rates when grown on reduced nitrogen sources such as ammonia and urea (Dortch, 1990; Bender et al., 2012), but also in some cases dominate environments when nitrate is the dominant source of DIN. Their ability to take up and flexibly utilize a range of nitrogen sources also likely contributes to their role as a dominant phytoplankton group. We suggest that $\mathrm{B}$ vitamin deprivation may impair the ability of diatoms to effectively respond to and recover from nitrogen deprivation and that this may have important implications for interactions between marine microbial groups. This results from the fact that metabolisms impacted by $B_{1}$ and $B_{12}$ have important roles in pathways and mechanisms for allocation of cellular $\mathrm{N}$ recovery from $\mathrm{N}$ starvation.

\section{B VITAMIN AND N INTERACTIONS IN OCEANIC ENVIRONMENTS}

It is clear that marine bacterial communities, in some cases, compete with eukaryotic phytoplankton for inorganic nitrogen sources, including nitrate (Kirchman and Wheeler, 1998; Kirchman, 2000; Allen et al., 2001, 2005). These heterotrophic bacterial communities also conduct the canonical transformation of organic $\mathrm{N}$ sources to ammonia and dissolved organic nitrogen via cycling within the microbial loop. As a result, bacterial communities can be either net sources or net sinks of available $\mathrm{N}$ to phytoplankton communities (Kirchman, 2000; Zehr and Ward, 2002). This may vary as a function of the C:N ratio of available organic matter as well as the community composition of microbial assemblages (Kirchman, 2000). There are clear parallels between $\mathrm{N}$ and $\mathrm{B}$ vitamin availability in the ocean; the interaction between marine microbial groups plays a key role in shaping the influence these chemicals have on productivity. As a result, the implications of combined nitrogen starvation and B vitamin deprivation for eukaryotic phytoplankton will clearly be interactively impacted by bacterial communities. Intimately associated bacterial communities, such as those shown in Figure 1, have the potential to impact vitamin availability as well as nitrogen resources to phytoplankton; interactions between $\mathrm{B}$ vitamin and $\mathrm{N}$ dynamics in algal bacterial associations have yet to be explored, but are intriguing areas for research.

There have been two studies examining interactive impact of DIN and B vitamin addition on phytoplankton communities. In Long Island embayments, shifts from dinoflagellate dominated, primarily $\mathrm{N}$ limited communities in summer to diatom dominated blooms in fall coincided with decreases in $\mathrm{B}_{12}$ and $B_{1}$ availability and increases in chlorophyll production upon $B$ vitamin additions, suggesting that $\mathrm{N}$ and $\mathrm{B}$ vitamin availability both influence coastal phytoplankton species succession and biomass. Interestingly, in several instances, $\mathrm{B}_{12}$ or $\mathrm{B}_{1}$ and nitrate, when added together, stimulated chlorophyll production to a greater degree than adding either nutrient alone (Gobler et al., 2007). This interactive effect has yet to be mechanistically explored, but could be a function of vitamins being independently 
secondarily limiting, or could be explained by biochemical interactions between nitrogen and B vitamin production or demand (Saito et al., 2008). In a series of bottle incubation studies in the coastal, nitrogen limited region of the Gulf of Alaska, the addition of nitrate alone yielded enhanced productivity, and a shift from a dinoflagellate to diatom dominated community. In contrast, the addition of $\mathrm{B}_{12}$ and nitrate together yielded a community dominated by dinoflagellates (Koch et al., 2011). This striking result suggests that $B$ vitamin availability severely impacted the response of the coastal phytoplankton community to nitrogen availability. This response suggests that the dinoflagellate community could not respond to nitrogen addition under $\mathrm{B}_{12}$ starvation conditions, either due to secondary, independent limitation of dinoflagellate growth by $\mathrm{B}_{12}$ availability or due to biochemical interactions between nitrogen and $\mathrm{B}_{12}$ metabolism leading to colimitation. Since a higher proportion of dinoflagellates are $\mathrm{B}_{12}$ auxtrophs (90\%) than are diatoms (60\%) (Tang et al., 2010), this response may be expected. However, diatom ability to respond to nitrogen additions over dinoflagellates under low $\mathrm{B}_{12}$ availability may not be entirely explained by differences in auxotrophy and warrants further exploration. Here we examine potential biochemical mechanisms for interaction between B vitamin and nitrogen metabolism.

\section{MOLECULAR RESPONSES OF EUKARYOTIC PHYTOPLANKTON TO B VITAMIN STARVATION}

There is some information available concerning the molecular responses of eukaryotic phytoplankton to B-vitamin starvation. While studies that examine the response of phytoplankton to $B_{1}$ deprivation have not been described in detail (McRose et al., 2012), there has been comparatively extensive inquiry into the molecular response of phytoplankton to $B_{12}$ deprivation. An important consequence of $\mathrm{B}_{12}$ deprivation in eukaryotic phytoplankton appears to be impaired methionine synthase activity and the use of $\mathrm{B}_{12}$-independant MetE over dependent MetH (Croft et al., 2005; Helliwell et al., 2011; Bertrand et al., 2012). Methionine serves not only as a protein-building amino acid but as the precursor to S-adenosylmethionine (AdoMet or SAM), an important methylating agent, propylamine donor, and radical source. Indeed, there is evidence that SAM deprivation is an important consequence of low $\mathrm{B}_{12}$ availability in diatoms (Bertrand et al., 2012; Figure 2). Notably, ThiC, an important algal thiamine biosynthesis protein, is SAM-dependant and responds to $B_{12}$ deprivation in diatom cultures, suggesting that there may be consequences of $\mathrm{B}_{12}$ deprivation for thiamine production. In addition, dinoflagellate transcriptome and metatranscriptome sequencing studies reveal that SAM cycling genes are among the most highly expressed transcripts in multiple dinoflagellate species (Lidie et al., 2005; Moustafa et al., 2010; Toulza et al., 2010). These data, along with the high percentage of surveyed dinoflagellates that exhibit an obligate $B_{12}$ requirement (>90\%; Tang et al., 2010) suggest that $\mathrm{B}_{12}$ availability may have important implications for dinoflagellate SAM metabolism; perhaps a disproportionately important process relative to diatoms. This could potentially result from extensive dinoflagellate DNA methylation or increased demand due to toxin production, which has a high SAM requirement (Lin, 2011). In addition, impaired
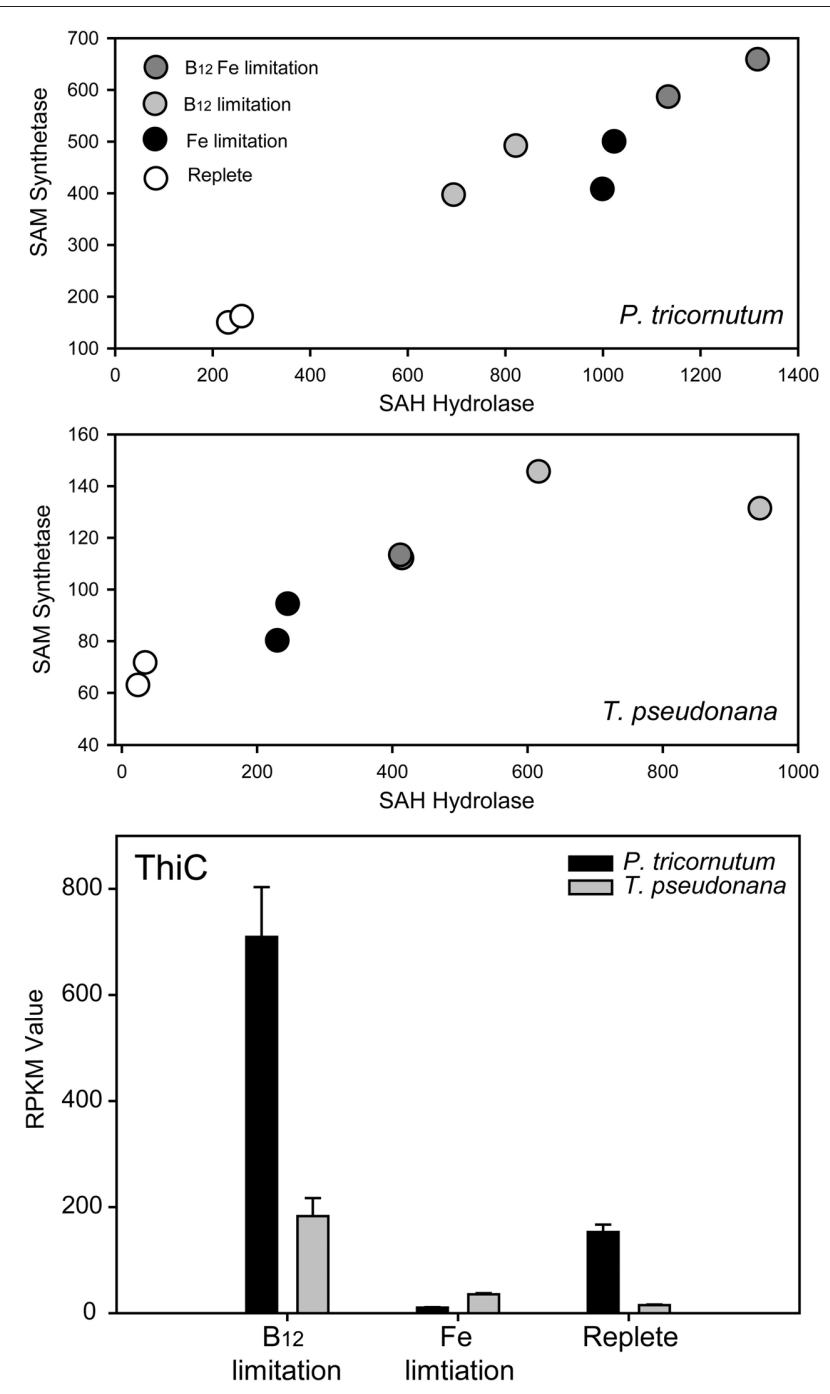

FIGURE 2 | Evidence from Bertrand et al., 2012 that AdoMet SAM starvation is an important consequence of $B_{12}$ deprivation, with implications for thiamine biosynthesis. SAM synthetase (Tp 39946, Pt 18319) converts methionine and ATP to SAM. SAM, after use for methylation reactions, is converted to S-adenosylhomocysteine (SAH). $\mathrm{SAH}$ can act as an inhibitor to methylation reactions because of its high affinity for most methyltranserfases. SAH hydrolase (Tp 28496; Pt bd 913) catalyzes the reversible interconversion of SAH to homocysteine and adenosine. The expression of the genes encoding these proteins in two diatoms appears to correlate. RPKM (Reads Per Kilobase of exon model per Million mapped reads) gene expression values are plotted against each other for each of eight samples in two diatoms, duplicates of replete, low $\mathrm{B}_{12}$, low $\mathrm{B}_{12}$ with low iron, and low iron alone. Expression under iron limited conditions was examined along with $B_{12}$ to verify whether changes induced were likely a general stress response or more specific to the vitamin. In both diatoms, cells grown under nutrient replete conditions express these genes at the lowest level. Iron and $\mathrm{B}_{12}$ availability both influence the expression of these genes, with $B_{12}$ having a greater impact of gene expression the $\mathrm{B}_{12}$ requiring diatom $T$. pseudonana. ThiC is a SAM-dependent protein required for pyrimidine moiety synthesis in thiamine biosynthesis. The expression of genes encoding ThiC in both these diatoms is elevated under low $B_{12}$ availability and not under low iron availability, suggesting that thiamine biosynthesis, and $B_{12}$ availability may be linked in these diatoms, potentially through $B_{12}$ impacts on SAM availability. 
methionine synthase activity prevents efficient folate recycling, which has important implications for nucleic acid biosynthesis (Scott and Weir, 1981; Croft et al., 2005). Molecular evidence for altered folate metabolism has also been documented as a significant component of the diatom response to $\mathrm{B}_{12}$ deprivation (Bertrand et al., 2012). This likely holds true for other algal groups as well since the diatom response is similar to distantly related organisms such as humans and other metazoans (e.g., Scott and Weir, 1981).

Molecular aspects of acquisition of these vitamins in eukaryotic algae remains poorly understood. An important result of these inquiries into the molecular response of algae to vitamin deprivation has been the identification of proteins that are potentially involved in $\mathrm{B}_{12}$ or $\mathrm{B}_{1}$ acquisition. Bertrand et al. (2012) identified a previously uncharacterized protein, deemed CBA1, that is directly involved in $B_{12}$ acquisition by diatoms and that is much more abundant in diatoms when they are experiencing $\mathrm{B}_{12}$ deprivation. This protein, however, appears to be restricted to the stramenopile lineage, suggesting that other eukaryotic algal groups utilize different, as of yet unidentified, pathways for $B_{12}$ uptake (Bertrand et al., 2012). Several candidate proteins involved in thiamine trafficking have been identified in whole genome sequencing projects (Worden et al., 2009) and transcriptomic analyses of Micromonas cultures under thiamine deprivation have also resulted in identification of additional putative thiamine transporters in this $\mathrm{B}_{1}$ auxotrophic group (McRose et al., 2012).

Examination of transcripts encoding CBA1, ThiC, MetE, and $\mathrm{MetH}$ in natural Antarctic diatom communities revealed that all these transcripts are relatively abundant and therefore that B vitamin metabolism is likely an important component of the molecular physiology of field communities (Figure 3). These expression patterns suggest that Antarctic diatom communities are experiencing $\mathrm{B}_{12}$ deprivation (expressing MetE and $\mathrm{CBA} 1$ ) and that some subset of the community is able to potentially utilize $B_{12}$ for methionine regeneration (MetH expression). This suggests that there are potentially different $\mathrm{B}_{12}$ quotas for different diatom species, with species experiencing starvation at varying intersections of cellular demand relative to ambient $B_{12}$ availability. Additionally, there may be a subset of diatoms with localized $\mathrm{B}_{12}$ sources, such as intimately attached bacteria (Figure 1). These results suggest, however, that examining the distribution of $\mathrm{B}_{12}$ responsive transcripts in field populations will yield important insights into the impact of vitamin availability on community

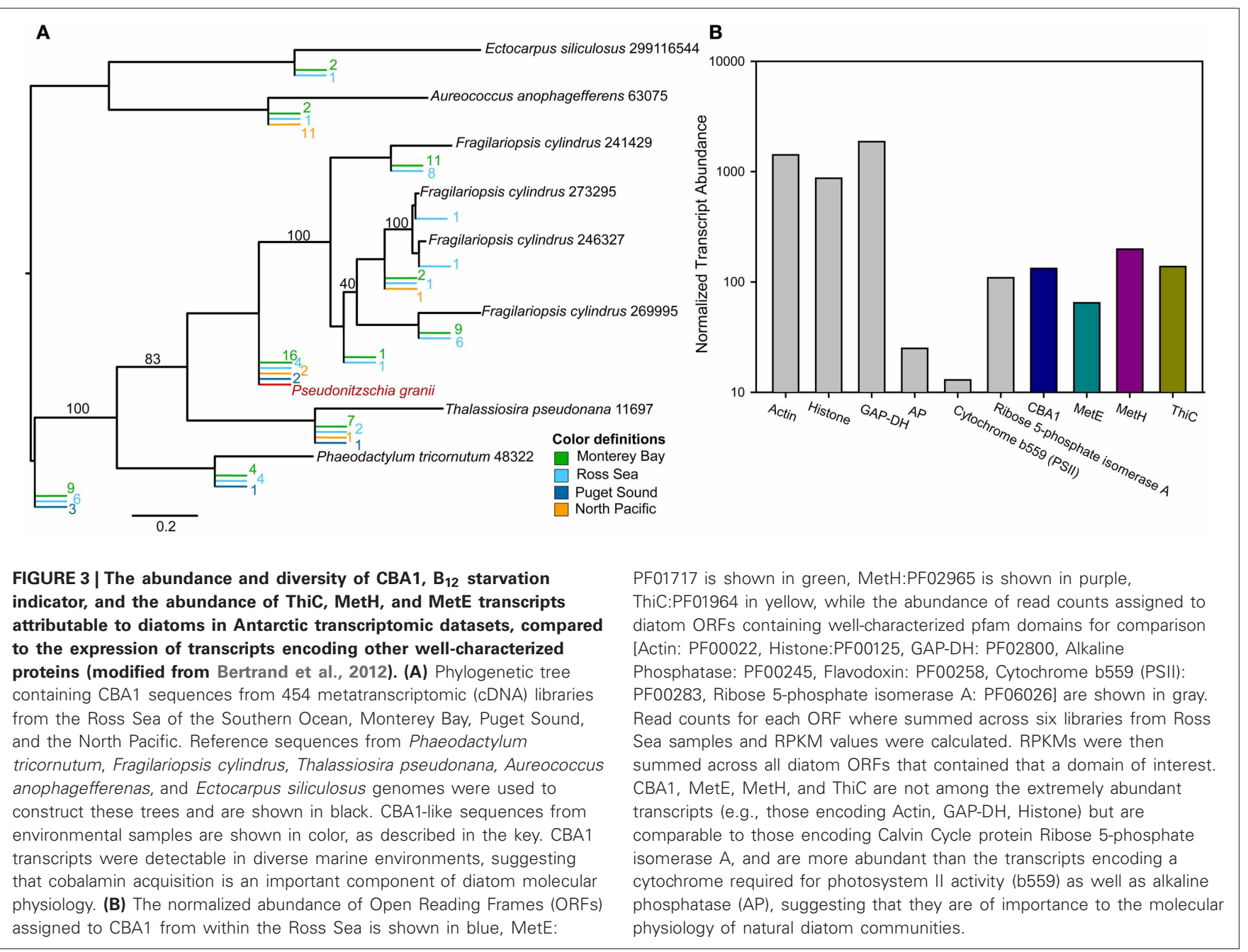


structure and primary productivity. For these analyses, it would be useful to know what percentage of the eukaryotic phytoplankton community possesses the ability to produce MetE; this would allow for more extensive interpretation of MetE and MetH transcript expression patterns. Similar analyses may be possible with thiamine-responsive genes in the future. Potential candidates for this include the recently identified putative transporters as well as ThiC, which appears to be present in genomes that are not auxotrophs and absent from genomes of organisms that require exogenous thiamine (Table 2).

\section{POTENTIAL B 12 AND B 1 METABOLIC INTERACTIONS WITH NITROGEN IN EUKARYOTIC PHYTOPLANKTON B VITAMIN AND N STARVATION IMPACTS ON OSMOLYTE PRODUCTION AND UTILIZATION}

Osmolytes are molecules that serve roles in osmoregulation. In eukaryotic phytoplankton, these include proline, glycine betaine (GBT), dimethylsulfonium propionate (DMSP), homarine, and isethionic acid (Boroujerdi et al., 2012). There are potentially important roles for $\mathrm{B}_{12}, \mathrm{~B}_{1}$, methionine, $\mathrm{SAM}$, and nitrogen metabolism in osmolyte production that likely result in interactive biochemical effects. One example is that methionine and SAM are both required for DMSP production, which is used by a subset of diatoms possibly as a cryoprotectant, osmolyte (Stefels, 2000), or antioxidant (Sunda et al., 2002), and is the precursor to the climatically important gas dimethylsulfide (Charlson et al., 1987). SAM recycling genes appear to play a role in the response of diatoms to low nitrogen, suggesting that there may be synergistic impacts of nitrogen and $B_{12}$ depletion on SAM availability (Table 4). This observation is intriguing and warrants further exploration via SAM metabolite analysis under conditions of varying $B_{12}$ and nitrogen availability.

In addition, nitrogen limitation has been previously identified as an important factor driving DMSP and DMS produced by phytoplankton populations. Nitrogen deprivation, more than any other nutrient starvation scenario tested, led to enhanced DMSP production per cell in an important oceanic diatom (Bucciarelli and Sunda, 2003; Sunda et al., 2007). A possible explanation for this trend is that under nitrogen starvation, $\mathrm{N}$-containing osmolytes such as proline, homarine, and GBT are replaced by DMSP, which does not contain nitrogen (Bucciarelli and Sunda, 2003). There is some evidence that under N-replete conditions, GBT and homarine replace DMSP in T. pseudonana and that GBT concentrations increase upon addition of $\mathrm{N}$ to $\mathrm{N}$-starved cultures of diatoms and coccolithophores (Keller et al., 1999). If DMSP is in fact used to replace $\mathrm{N}$-containing osmolytes, $\mathrm{B}_{12}$ starvation coupled with $\mathrm{N}$-limitation has the potential to negatively impact that substitution in at least two ways. The first is by potentially limiting the amount of DMSP produced due to restricted methionine availability. The second is again through SAM deprivation, which has been hypothesized to play an important role in diatom metabolism under low $\mathrm{B}_{12}$ conditions (Figure 3; Bertrand et al., 2012). These metabolic connections suggest that there may be synergistic impacts of $\mathrm{B}_{12}$ and $\mathrm{N}$ starvation on DMSP-producing algal strains. Alternatively, if the primary function for DMSP is as an antioxidant, increases in DMSP as a function of nitrogen starvation could be due to elevated demand for DMSP under the oxidative stress induced by nitrogen deprivation (Sunda et al., 2002, 2007). If DMSP in fact serves an important antioxidant role and if thiamine is shown to be an important algal antioxidant as well, this suggests that there could be potentially important interactions between $\mathrm{B}_{1}, \mathrm{~B}_{12}$, and $\mathrm{N}$ availability in algal cells in response to oxidative stress.

Synthesis of GBT, in many organisms, also requires SAM as a methyl group donor. Also like DMSP, there is evidence that GBT production is tied to nitrogen metabolic status of individual cultures, (Keller et al., 1999, 2004). Since GBT synthesis requires nitrogen and is likely SAM dependent, $\mathrm{B}_{12}$ starvation may prompt substitution of other osmolytes, such as proline, for GBT as well as DMSP. This may have important implications for cellular nitrogen cycling. Notably, proline is generated from ornithine via activity of ornithine cyclodeaminase. Ornithine is an important metabolite in the urea cycle, which is a major pathway for nitrogen recycling in diatoms and potentially other algae (Fernie et al., 2012). If the proline balance were significantly impacted as a result of a metabolic cascade resulting from changes in the osmolyte balance, this could have significant impacts on overall cellular nitrogen metabolism.

\section{$B_{12}$ AND $B_{1}$ STARVATION IMPACTS ON AMINO ACID AND POLYAMINE BIOSYNTHESIS}

The major organic constituent of diatom silica frustules are a series of long chain polyamines (LCPAs). Different diatoms synthesize different suites of LCPAs (Kroger et al., 2000). These molecules, along with silica deposition proteins called silafins and silafin-like girdle band and nanopattern-associated proteins call cingulins (Scheffel et al., 2011), induce biomineralization, and are responsible for differences in frustule morphology between diatom groups. LCPAs vary in chain length and degree of methylation, but appear to all be synthesized from putricine, spermidine, or spermine precursors. These precursors are synthesized sequentially from ornithine, with spermidine, and spermine production both requiring SAM as a propylamine donor. Subsequent steps in LCPA formation likely require SAM as well (Kroger and Poulsen, 2008). LCPAs recovered in net tows are mostly putracine-based, with varying degrees of methylation, suggesting that SAM is an important component of LCPA production for field diatom populations as well (Bridoux et al., 2012). Conceivably, reduced SAM production through $\mathrm{B}_{12}$ starvation could induce changes in silica frustule formation by decreasing the pool of available LCPAs. Indeed, reduction of LCPA production as a result of the addition of an inhibitor for ornithine decarboxylase, which is known to be involved in polyamine biosynthesis, dramatically reduced biogenic silica formation in T. pseudonana (Frigeri et al., 2006). In diatoms, possible LCPA biosynthesis genes have been identified. These are potentially gene fusions of bacterially derived polyamine biosynthetic enzymes S-adenosylmethionine decarboxylase (SAM DC) and an aminopropyltransferase (Michael, 2011), which require input of SAM. The Met salvage pathway would need to be efficient, and if SAM starvation does result from $B_{12}$ deprivation, there could be substantial implications of low $\mathrm{B}_{12}$ for LCPA biosynthesis. Ornithine represents a significant component of the carbon and nitrogen pool within phytoplankton cells and is a centrally important 
Table 4 | $\mathrm{B}_{12}$ and $\mathrm{B}_{1}$ related genes from published $P$. tricornutum EST libraries.

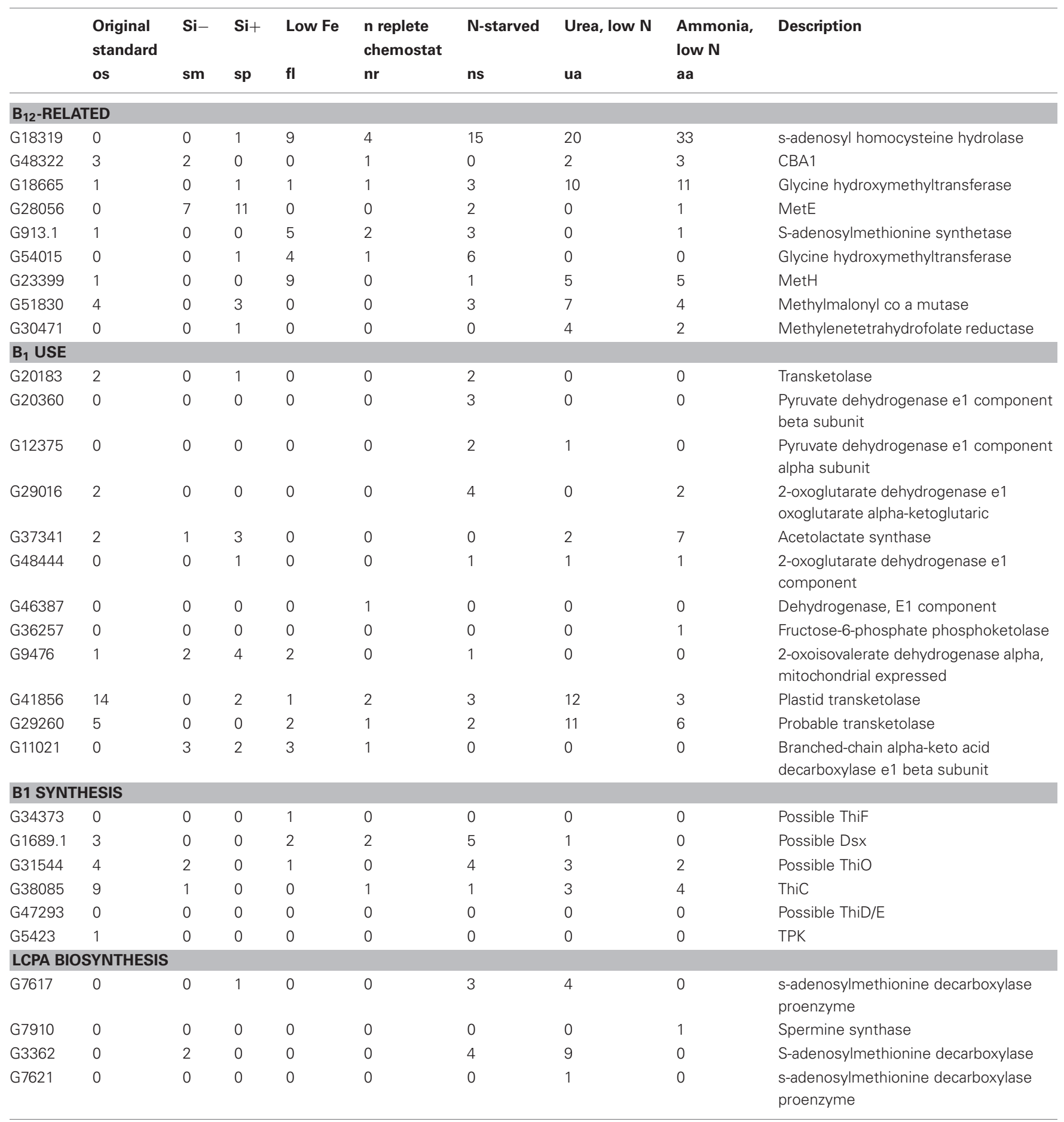

Treatment descriptions and labels can be found in Maheswari et al. (2010).

metabolite in the ornithine urea cycle (OUC), which is the major distribution hub for nitrogen in diatom cells (Allen et al., 2011; Bender et al., 2012). If SAM starvation results in major changes in ornithine balance through alterations in polyamine biosynthesis, this would hold substantial ramifications for the impact of $B_{12}$ deprivation on nitrogen cycling.
Overall, it seems that $\mathrm{N}$ starvation could induce upregulation in pathways that demand $\mathrm{B}_{12}$, such as methionine and SAM synthesis. This would potentially be reflected in elevated expression of $\mathrm{B}_{12}$ acquisition proteins under nitrogen limitation, and elevation of proteins required to generate methionine. 


\section{LINKS BETWEEN N, $B_{1}$ AND $B_{12}$ THROUGH SULFUR METABOLISM IN EUKARYOTIC PHYTOPLANKTON}

Connections between nitrate reduction and sulfur assimilation are well known. Sulfate reduction is thought to be regulated by nitrogen nutrition in plants (Koprivova et al., 2000; Takahashi et al., 2011); this may also be true for phytoplankton, as sulfur uptake and assimilation genes in diatoms appear to be responsive to nitrogen availability. Both $B_{1}$ and $B_{12}$ have important ties to sulfur metabolism, since $B_{12}$ is important for sulfur amino acid cycling and DMSP synthesis and $\mathrm{B}_{1}$ is produced from thiazole, a sulfur containing moiety. Indeed, in plants, methionine synthesis and other aspects of sulfur metabolism are very tightly regulated by SAM availability. If the $B_{12}$ dependence of SAM availability hypothesized for phytoplankton is verified (Bertrand et al., 2012), this suggests that $B_{12}$ availability may influence additional aspects of sulfur and nitrogen metabolism.

\section{INFLUENCE OF $B_{12}$ AND $B_{1}$ STARVATION ON THE DIATOM UREA CYCLE THROUGH IMPACTS ON THE CITRIC ACID CYCLE AND AMINO ACID CYCLING}

Important impacts of vitamins on amino acid and amine cycling include the previously discussed impact of $\mathrm{B}_{12}$ on cysteine and methionine cycling and the impact of $\mathrm{B}_{1}$ on branched amino acid synthesis. $B_{1}$ contributes to the first step in valine synthesis as well as important steps in amino acid degradation and recycling via keto acid dehydrogenase activity (Binder et al., 2007). In addition, $B_{1}$ appears to impact nitrogen assimilation and amino acid recycling though the dependence of 2-oxoglutarate dehydrogenase (OGDHC) on the cofactor (Bunik and Fernie, 2009). For instance, potato $\mathrm{OGDHC}$ inhibition causes reductions in nitrate assimilation as well as increases in glutamate and GABA accumulation (Araujo et al., 2008). This suggests that disturbances in $\mathrm{B}_{1}$ metabolism may have profound affects for nitrogen assimilation and amino acid recycling, though this has yet to be confirmed for phytoplankton.

The OUC is of central importance to diatoms and potentially other phytoplankton as a nitrogen assimilation and repackaging hub. The OUC and the citric acid (TCA) cycles are linked (Allen et al., 2011). Mitochondrial amino acid catabolism yield carbon skeletons for the TCA cycle as well as ammonia and bicarbonate that is shunted into the OCU. This connection is supported by metabolic data suggesting that fumarate and malate, important TCA cycle intermediates, display similar patterns as OUC metabolites in diatom cell lines with altered urea cycle pathways (CPS knockdowns; Allen et al., 2011). Both $B_{12}$ and $B_{1}$ play important roles in the citric acid (TCA) cycle. For example, $B_{12}$ is a cofactor for mmcM which generates succinyl coA from methylmalonyl coA, an amino acid degradation product. Expression of the gene encoding $\mathrm{mmcM}$ is upregulated under $-\mathrm{N}$ conditions in P. tricornutum EST libraries (Table 4), suggesting that there could be consequences of reduced mmcM activity for cells experiencing nitrogen deprivation. $\mathrm{B}_{12}$ availability does not appear to influence mmcM expression (Bertrand et al., 2012). It is notable that mmcM expression levels are not insignificant in diatom transcriptome studies, suggesting that this gene product may be of utility to phytoplankton despite the fact that the presence of this gene in phytoplankton genomes does not confer an absolute $\mathrm{B}_{12}$ demand (Table 1). There are numerous connections between $B_{1}$ and the citric acid cycle. B1 is required for the generation of acetyl CoA from pyruvate via the pyruvate dehydrogenase complex. The enzyme ODG is also thiamine-dependent and plays a important role in the citric acid cycle. This enzyme is also thought to be a important player in plant nitrogen assimilation though its impact on glutamine stores (Bunik and Fernie, 2009). Interestingly, the reactant consumed by this protein, 2-oxoglutarate, accumulates strongly in diatom cell lines with impacted urea cycle (Allen et al., 2011). These data suggest that $B_{1}$ - and $B_{12}$-dependent metabolisms play key roles in steps that maintain cellular carbon and nitrogen recycling; synergistic impacts of B vitamin deprivation and $\mathrm{N}$ starvation are therefore likely.

\section{SYNTHESIS AND IMPLICATIONS FOR EUKARYOTIC PHYTOPLANKTON ECOLOGY}

Many of the interactions between $\mathrm{B}$ vitamins and $\mathrm{N}$ metabolism described above have the potential to profoundly influence eukaryotic phytoplankton ecology and are summarized in Figure 4. From these interactions, we can hypothesize that nitrogen limitation, experienced by phytoplankton in much of the ocean, may induce enhanced demand for $\mathrm{B}_{12}$ and $\mathrm{B}_{1}$ via a variety of mechanisms. These include substitution of $\mathrm{N}$-containing osmolytes with DMSP, substituting N-containing antioxidants and DMSP with thiamine, and effectively recycling amino acids and glutamine stores utilizing high amounts of $\mathrm{B}_{1}$. There are also interactions discussed above that would result in B vitamin deprivation leading to impaired nitrogen recycling which could conceivably increase nitrogen demand in phytoplankton cells. These include impaired glutamine recycling due to reduced 2-oxogultarate dehydrogenase and pyruvate dehydrogenase activity and impaired ornithine and proline cycling due to $B_{1}$ and $B_{12}$ impacts on the TCA cycle as well as through potential imbalances in the methyl cycle due to $B_{12}$ deprivation. These mechanisms all suggest that biochemical interactions between $\mathrm{B}$ vitamin and $\mathrm{N}$ limitation have the potential to lead to interactive colimitation and thus that the $\mathrm{B}$ vitamin and $\mathrm{N}$ colimitations observed in field studies (Koch et al., 2011; Gobler et al., 2007) may be due to both independent secondary limitation or dependent colimitation scenarios (Saito et al., 2008).

These biochemical dependencies have the potential to impart changes in phytoplankton species composition based on differences in $\mathrm{B}_{1}$ and $\mathrm{B}_{12}$ demand between phytoplankton groups. Diatoms are thought to rely on an efficient urea cycle for distributing and recycling nitrogen (Allen et al., 2011; Bender et al., 2012). The impacts of $B_{12}$ and $B_{1}$ deprivation on the efficiency of the urea cycle, therefore, may disproportionately impact diatoms. In addition, if dinoflagellate SAM demand is indeed elevated over other phytoplankton as hypothesized, it is possible that $B_{12}$ deprivation could disproportionately impact dinoflagllate strategies for coping with nitrogen deprivation, such as the use of DMSP to replace $\mathrm{N}$-containing osmolytes. These impacts may be of particular importance to harmful algal bloom species, which are known to have disproportionately high instances of $\mathrm{B}_{1}$ and $\mathrm{B}_{12}$ auxotrophy (Tang et al., 2010). Additionally, toxin production by some dinoflagellate species has been shown to 


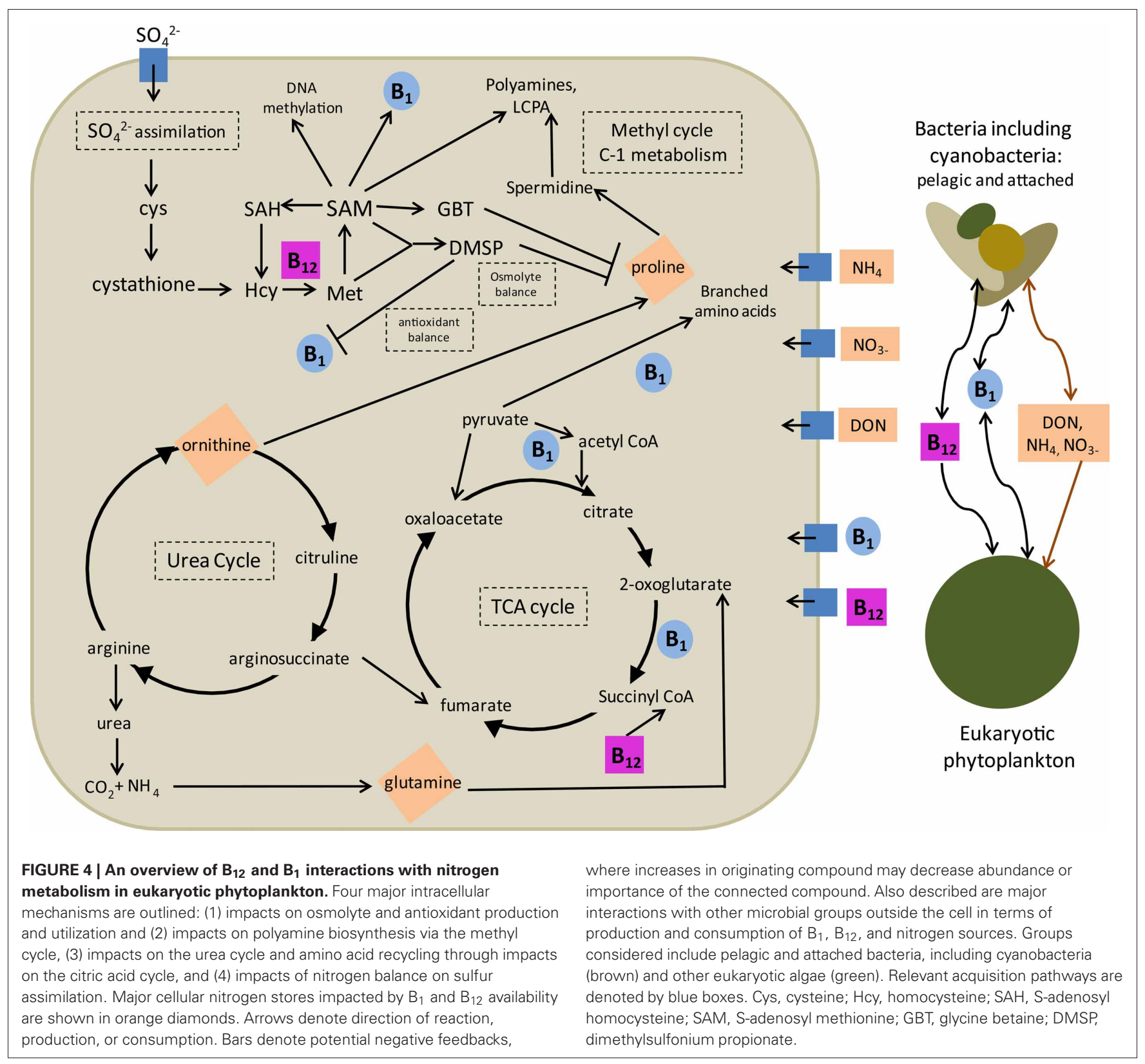

increase under N-limitation (Ransom Hardison et al., 2012); synthesis pathways of many dinoflagellate toxins such as saxitoxin and brevetoxin are thought to be SAM-dependent (Lin, 2011). Together, these data suggests that HAB species may be more susceptible than others to impacts of these dependent colimitations between $\mathrm{N}$ and $\mathrm{B}$ vitamins and that these colimitations may additionaly impact toxin production rates. This is further evidence that B vitamin dynamics should be considered when predicting and evaluating potential for harmful algal bloom scenarios.

Given that $\mathrm{B}_{12}, \mathrm{~B}_{1}$, and nitrogen availability to eukaryotic phytoplankton all have potential to be impacted by bacterial community composition and activity, the bacterial community is likely an important driver of when and where instances of these dependent colimitations may be important. This may be especially true when considering timing and species composition in spring bloom scenarios, which is an active area of continued research today (Mahadevan et al., 2012). Swift and Guillard (1978) determined that spring bloom diatom species, though not $\mathrm{B}_{12}$ auxotrophs, grew faster and experienced shorter lag phases in the presence of the vitamin, suggesting that possible interactions between $\mathrm{N}$ and $\mathrm{S}$ metabolism, and $\mathrm{B}_{12}$ utilization could be important for bloom timing and species composition. Recent work also suggests that bacterioplankton respond to various phases in spring blooms by changing both metabolic potential and species composition over time (Teeling et al., 2012). This could have important impacts for $\mathrm{B}_{12}$ and $\mathrm{B}_{1}$ production and consumption as well as for nitrogen availability and recycling. Mounting evidence 
suggests that there could be synergistic interactions of these impacts on eukaryotic phytoplankton that could influence not only species composition but also bloom timing and overall productivity. This suggests that time series measurements, over both day to week and seasonal timescales, which include $\mathrm{B}_{12}, \mathrm{~B}_{1}$, and nitrogen species concentration measurements and uptake rates as well as protein or transcript-based indicators of nitrogen and vitamin deprivation, would be useful, particularly in conjunction with bacterioplankton community composition assessments and implementation of B vitamin biosynthesis indicators. Locations where this would be of considerable interest include high latitude ecosystems, which largely lack $\mathrm{B}_{12}$ producing cyanobacteria, coastal locations with HAB blooming dinoflagellates, and diatoms as well as the North Atlantic, before during and after bloom scenarios.

\section{ACKNOWLEDGMENTS}

We thank Greg Wanger for the use of his electron microscopy images. We are indebted to Mak Saito, Peter Lee, Ruben Valas, Stephane Lefebvre, James McCarthy, Jeff McQuaid, and Karen Beeri for helpful discussions. This work was funded by an NSF Office of Polar Programs Postdoctoral Fellowship to Erin M. Bertrand (ANT-1103503) and NSF-MCB-1024913, NSF-ANT1043671, and DOE-DE-SC0006719 (Andrew E. Allen).

\section{REFERENCES}

Allen, A., Dupont, C. L., Obornik, M., Horak, A., Nunes-Nesi, A., McCrow, J. P., et al. (2011). Evolution and metabolic significance of the urea cycle in photosynthetic diatoms. Nature 473, 203-206.

Allen, A. E., Booth, M. G., Frischer, M. E., Verity, P. G., Zehr, J. P., and Zani, S. (2001). Diversity and detection of nitrate assimilation genes in marine bacteria. Appl. Environ. Microbiol. 67, 5343-5348.

Allen, A. E., Booth, M. G., Verity, P. G., and Frischer, M. E. (2005). Influence of nitrate availability on the distribution and abundance of heterotrophic bacterial nitrate assimilation genes in the Barents Sea during summer. Aquat. Microb. Ecol. 39, 247-255.

Araujo, W. L., Nunes-Nesi, A., Trenkamp, S., Bunik, V. I., and Fernie, A. R. (2008). Inhibition of 2-oxoglutarate dehydrogenase in potato tuber suggests the enzyme is limiting for respiration and confirms its importance in nitrogen assimilation. Plant Physiol. 148, 1782-1796.

Azam, F. (1998). Microbial control of oceanic carbon flux: the plot thickens. Science 280, 694-696.

Bender, S. J., Parker, M. S., and Armbrust, E. (2012). Coupled effects of light and nitrogen source on the urea cycle and nitrogen metabolism over a diel cycle in the marine diatom Thalassiosira pseudonana. Protist 163, 232-251.

Bertrand, E. M., Allen, A. E., Dupont, C. L., Norden-Krichmar, T. M., Bai, J., Valas, R. E., et al. (2012). Influence of cobalamin scarcity on diatom molecular physiology and identification of a cobalamin acquisition protein. Proc. Natl. Acad. Sci. U.S.A. 109, E1762-E1771.

Bertrand, E. M., Saito, M. A., Jeon, Y. J., and Neilan, B. A. (2011a). Vitamin $\mathrm{B}_{12}$ biosynthesis gene diversity in the Ross Sea: the identification of a new group of putative polar $\mathrm{B}_{12}$ biosynthesizers Environ. Microbiol. 13, 1285-1298.

Bertrand, E. M., Saito, M. A., Lee, P. A., Dunbar, R. B., Sedwick, P. N., and DiTullio, G. R. (2011b). Iron limitation of a springtime bacterial and phytoplankton community in the Ross Sea: implications for vitamin $\mathrm{B}_{12}$ nutrition. Front. Aquat. Microbiol. 2:160. doi: 10.3389/fmicb.2011.00160

Bertrand, E. M., Saito, M. A., Rose, J. M., Riesselman, C. R., Lohan, M. C., Noble, A. E., et al. (2007). Vitamin B12 and iron co-limitation of phytoplankton growth in the Ross Sea. Limnol. Oceanogr. 52, 1079-1093.

Bettendorff, L., and Wins, P. (2009). Thiamin diphosphate in biological chemistry: new aspects of thiamin metabolism, especially triphosphate derivatives acting other than as cofactors. FEBS J. 76, 2917-2925.

Binder, S., Knill, T., and Schuster, J. (2007). Branched-chain amino acid metabolism in higher plants. Physiol. Plant. 129, 68-78.

Bonnet, S., Webb, E. A., Panzeca, C., Karl, D. M., Capone, D. G., and Sanudo-Wilhelmy, S. A. (2010). Vitamin $\mathrm{B}_{12}$ excretion by cultures of the marine cyanobacteria Crocosphaera and Synechococcus. Limnol. Oceanogr. 55, 1959-1964.

Boroujerdi, A. F. E., Lee, P. A., DiTullio, G. R., Janech, M. G., Vied, S. B., and Bearden, D. W. (2012). Identification of isethionic acid and other small molecule metabolites of Fragilariopsis cylindrus with nuclear magnetic resonance Anal. Bioanal. Chem. 404, 777-784.

Bridoux, M. C., Keil, R., and Ingalls, A. E. (2012). Analysis of natural diatom communities reveals novel insights into diversity of long chain polyamine structures involved in silica precipitation. Org. Geochem. 47, 9-21.

Bronk, D. A., Glibert, P. M., and Ward, B. B. (1994). Nitrogen uptake, dissolved organic nitrogen release, and new production. Science 265, 1843-1846.

Bucciarelli, E., and Sunda, W. G. (2003). Influence of CO2, nitrate, phosphate, and silicate limitation on intracellular DMSP in batch cultures of the coastal diatom Thalassiosira pseudonana. Limnol. Oceanogr. 48, 2256-2265.

Bunik, V. I., and Fernie, A. R. (2009). Metabolic control exerted by the 2-oxoglutarate dehydrogenase reaction: a cross-kingdom comparison of the crossroads between energy production and nitrogen assimilation. Biochem. J. 422, 405-421.

Capone, D. G. (2000). "The marine microbial nitrogen cycle," in Microbial Ecology of the Oceans, ed D. Kirchman (New York, NY: Wiley Liss), 455-494.

Carlucci, A. F. (1966). Bioassay of seawater. II. Methods for the determination of vitamin B1 in seawater. Can. J. Microbiol. 12, 1079-1089.

Carlucci, A. F., and Bowes, P. M. (1970). Production of vitamin $\mathrm{B}_{12}$, thiamine, and biotin by phytoplankton. J. Phycol. 6, 351-357.

Carlucci, A. F., and Silbernagel, S. B. (1969). The effect of viamin concentrations on growth and development of vitamin-requiring algae. J. Phycol. 5, 64-67.

Carlucci, A. F., Silbernagel, S. B., and McNally, P. M. (1969). The influence of temperature and solar radiation on persistence of vitamin $B_{12}$, thiamine, and biotin in seawater. J. Phycol. 5, 302-305.

Caron, D. A., Dennett, M. A., Lonsdale, D. J., Moran, D. M., and Shalapyonok, L. (2000). Microzooplankton herbivory in the Ross Sea, Antarctica. Deep Sea Res. II 47, 3249-3272.

Charlson, R. J., Lovelock, J. E., Andreae, M. O., and Warren, S. G. (1987). Oceanic phytoplankton, atmospheric sulphur, cloud albedo, and climate. Nature 326, 655-661.
Chatterjee, A., Li, S., Zhang, Y., Grove, T. L., Lee, M., Krebs, C., et al. (2008). Reconstitution of ThiC in thiamine pyrimidine biosynthesis expands the radical SAM superfamily. Nat. Chem. Biol. 4, 758-765.

Cole, J. J. (1982). Interactions between bacteria and algae in aquatic systems. Annu. Rev. Ecol. Sys. 13, 291-314.

Cowey, C. B. (1956). A preliminary investigation of the variaton of vitamin B-12 in oceanic and coastal waters. J. Mar. Biol. Assoc. U.K. 35, 609-620.

Croft, M. T., Lawrence, A. D., RauxDeery, E., Warren, M. J., and Smith, A. G. (2005). Algae acquire vitamin B12 through a symbiotic relationship with bacteria. Nature 438, 90-93.

Croft, M. T., Moulin, M., Webb, M. E., and Smith, A. G. (2007). Thiamine biosynthesis in algae is regulated by riboswitches. Proc. Natl. Acad. Sci. U.S.A. 104, 20770-20775.

Croft, M. T., Warren, M. J., and Smith, A. G. (2006). Algae need their vitamins. Eukaryot. Cell 5, 1175-1184.

Dortch, Q. (1990). The interaction between ammonium and nitrate uptake in phytoplankton. MEPS 61, 183-201.

Drennan, C. L., Matthews, R. G., and Ludwig, M. L. (1994). Cobalamindependent methoionine synthase: the structure of a methylcobalaminbinding fragment and implicatiosn for other $\mathrm{B}_{12}$-dependent enzymes. Curr. Opin. Struct. Biol. 4, 919-929.

Droop, M. R. (1957). Vitamin $B_{12}$ in marine ecology. Nature 180, 1041-1042.

Droop, M. R. (1958). Requirement for thiamine among some marine and supralittoral protists. J. Mar. Biol. Assoc. U.K. 37, 323-329.

Droop, M. R. (1962). "Organic micronutrients," in Physiology and Biochemistry of Algae, ed R. A. Lewin (New York, NY: Academic Press), 141-159. 
Droop, M. R. (2007). Vitamins, phytoplankton and bacteria: symbiosis or scavenging? J. Plankton Res. 29, 107-113.

Eppley, R. W., and Peterson, B. J. (1979). Particulate organic matter flux and planktonic new production in the deep ocean. Nature 282, 677-680.

Fernie, A. R., Obata, T., Allen, A. E., Araújo, W. L., and Bowler, C. (2012). Leveraging metabolomics for functional investigations in sequenced marine diatoms. Trends Plant Sci. 17, 395-403.

Frank, R., Leeper, F., and Luisi, B. (2007). Structure, mechanism and catalytic duality of thiaminedependent enzymes. Cell. Mol. Life Sci. 64, 892-905.

Frigeri, L. G., Radabaugh, T. R., Haynes, P. A., and Hildebrand, M. (2006). Identification of Proteins from a cell wall fraction of the diatom Thalassiosira pseudonana. Mol. Cell. Proteomics 5, 182-193.

Gobler, C. J., Norman, C., Panzeca, C., Taylor, G. T., and SanudoWilhelmy, S. A. (2007). Effect of Bvitamins and inorganic nutrients on algal bloom dynamics in a coastal ecosystem. Aquat. Microb. Ecol. 49, 181-194.

Gold, K. (1968). Some factors affecting the stability of thiamine. Limnol. Oceanogr. 13, 185-188.

Gold, K., Roels, O. A., and Bank, H. (1966). Temperature dependent destruction of thiamine in seawater. Limnol. Oceanogr. 12, 410-413.

Goyer, A. (2010). Thamine in plants: aspects of its metabolism and functions. Phytochemistry 71, 1615-1624.

Grossart, H., Levold, F., Allgaier, M., and Brinkhoff, S. M. (2005). Marine diatom species harbour distinct bacterial communities. Environ. Microbiol. 7, 860-873.

Guillard, R. R. L., and Ryther, J. H. (1962). Studies of marine planktonic diatoms 1. Cyclotella nana Hustedt, and Detonula confervacea (cleve) Gran. Can J. Microbiol. 8, 229-239.

Hecky, R. E., and Killam, (1988). Nitrogen limitation of phytoplankton in freshwater and marine environments: a review of recent evidence on the effects of enrichment. Limnol. Oceanogr. 33, 796-822.

Helliwell, K. E., Wheeler, G. L., Leptos, K. C., Goldstein, R. E., and Smith, A. G. (2011). Insights into the evolution of vitamin $\mathrm{B}_{12}$ auxotrophy from sequenced algal genomes. $\mathrm{Mol}$. Biol. Evol. 28, 2921-2933.

Hu, M., Chen, Y., and Lin, Y. (1995). The antioxidant and prooxidant activity of some B vitamins and vitamin-like compounds. Chem. Biol. Interact. 97, 63-73.

Jurgenson, C. T., Begley, T. P., and Ealick, S. E. (2009). The structural and biochemical foundations of thiamine biosynthesis. Annu. Rev. Biochem. 78, 569-603.

Karl, D. M. (2002). Nutrient dynamics in the deep blue sea. Trends Microbiol. 10, 410-418.

Keller, M. D., Keine, R. P., Matrai, P. A., and Bellows, W. K. (1999). Production of glycine betaine and DMSP in marine phytoplankton 1. Batch cultures. Mar. Biol. 135, 237-248.

Keller, M. D., Matrai, P. A., Keine, R. P., and Bellows, W. K. (2004). Responses of coastal phytoplankton populations to nitrogen addition: dynamics of cell-associated DMSP, GBT and homarine. Can. J. Fish. Aquat. Sci. 61, 685-699.

Kirchman, D. (2000). "Uptake and regeneration of inorganic nutrients by marine heterotrophic bacteria," in Microbial Ecology of the Oceans, ed D. Kirchman (New York, NY: Wiley Liss), 261-288.

Kirchman, D. L., and Wheeler, P. A. (1998). Uptake of ammonium and nitrate by heterotrophic bacteria and phytoplankton in the subArctic Pacific. Deep Sea Res. I 45, 347-365.

Koch, F., Marcoval, M. A., Panzeca, C., Bruland, K. W., Sanudo-Wilhelmy, S. A., and Gobler, C. J. (2011). The effect of vitamin $B_{12}$ on phytoplankton growth and community structire in the Gulf of Alaska. Limnol. Oceanogr. 56, 1023-1034.

Koprivova, A., Suter, M., Op den Camp, R., Brunold, C., and Kopriva, S. (2000). Regulation of sulfate assimilation by nitrogen in Arabadopsis. Plant Physiol. 122, 737-746.

Kroger, N., Deutzmann, R., Bergsdorf, C., and Sumper, M. (2000). Species-specific polyamines from diatoms control silica morphology. Proc. Natl. Acad. Sci. U.S.A. 97, 14133-14138.

Kroger, N., and Poulsen, N. (2008). Diatoms- from cell wall biogeneisis to nanotechnology. Annu. Rev. Genet. 42, 83-107.

Kudela, R. M., and Dugdale, R. C. (2000). Nutrient regulation of phytoplankton productivity in Monterey Bay, CA. Deep Sea Res. II 47, 1023-1053.

Lexa, D., and Savant, J. M. (1983). The electrochemistry of vitamin B12. Acc. Chem. Res. 16, 235-243.

Lidie, K. B., Ryan, J. C., Barbier, M., and Van Dolah, F. M. (2005). Gene expression in Florida red tide dinoflagellate Karenia brevis. Mar. Biotechnol. 7, 481-493.

Lin, S. (2011). Genomic understanding of dinoflagellates. Res. Microbiol. 162, 551-569.

Lukienko, P. I., Melnichenko, N. G., Zverinskii, I. V., and Zabrodskaya, S. V. (2000). Antioxidant properties of thiamine. Bull. Exp. Biol. Med. 130, 874-876.

Mahadevan, A., D'Asaro, E., Lee, C. and Perry, M. J. (2012). Eddydriven stratification initiates North Atlantic spring phytoplankton blooms. Science 337, 54-58.

Maheswari, U., Jabbari, K., Petit, J. L., Porcel, B. M., Allen, A. E., Cadoret, J. P., et al. (2010). Digital gene expression profiling of novel diatom transcripts provides insight into their biological functions. Genome Biol. 11, R85.

Marchant, H. J. (2005). “Cyanophytes," in Antarctic Marine Protists, eds F. J. Scott and H. J. Marchant (Hobart: Australian Biological Resources Study), 324-325

Martens, J. H., Bargv, H., Warren, M. J., and Jan, D. (2002). Microbial production of vitamin $\mathrm{B}_{12}$. Appl. Microbiol. Biotechnol. 58, 275-285.

McCarthy, J. J., and Carpenter, E. J. (1983). "Nitrogen cycling in the near surface waters of the open ocean," in Nitrogen in the Marine Environment, eds E. J. Carpenter and D. G. Capone (New York, NY: Academic Press), 487-572.

McRose, D., Yan, S., Reistetter, E., and Worden, A. Z. (2012). "Vitamin biosynthesis and regulation in marine algae," in Genomics Science Contractors-Grantees Meeting, (Bethesda, MD).

Menzel, D. W., and Spaeth, J. P. (1962). Occurrence of vitamin $\mathrm{B}_{12}$ in the Sargasso Sea. Limnol. Oceanogr. 7, 151-154.

Michael, A. J. (2011). Molecular machines encoded by bacteriallyderived multidomain gene fusions that potentially synthesize $\mathrm{N}$ methylate and tranfer long chain polyamines in diatoms. FEBS Lett. 585, 2627-2634.

Moore, J. K., Doney, S. C., and Lindsay, K. (2004). Upper ocean ecosystem dynamics and iron cycling in a global three-dimensional model. Glob. Biogeochem. Cycles 18, 4028-4049.

Moustafa, A., Evans, A. N., Kulis, D. M., Hackett, J. D., Erdner, D. L., Anderson, D. M., et al. (2010). Transcriptome profiling of a toxic dinoflagellate reveals a gene-rich protist and a potential impact on gene expression due to bacterial presence. PLoS ONE 5:e9688. doi: 10.1371/journal.pone.0009688

Okbamichael, M., and SañudoWilhelmy, S. A. (2004). A new method for the determination of Vitamin $\mathrm{B}_{12}$ in seawater. Anal. Chim. Acta 517, 33-38.

Okbamichael, M., and SanudoWilhelmy, S. A. (2005). Direct determination of vitamin B1 in seawater by solid phase extraction and high performance liquid chromatography quantification. Limnol. Oceanogr. Methods 3, 241-246.

Panzeca, C., Beck, A., Leblanc, K., Taylor, G. T., Hutchins, D. A., and Sañudo-Wilhelmy, S. A. (2008). Potential cobalt limitation of vitamin $B_{12}$ synthesis in the North Atlantic Ocean. Glob. Biogeochem. Cycles 22, 2029-2036.

Panzeca, C., Beck, A. J., Tovar-Sanchez, A., Segovia-Zavala, J., Taylor, G. T., Gobler, C. J., et al. (2009). Distributions of dissolved vitamin B12 and Co in coastal and openocean environments. Estuar. Coast. Shelf Sci. 85, 223-230.

Panzeca, C., Tovar-Sanchez, A., Agusti, S., Reche, I., Duarte, M., Taylor, G. T., et al. (2006). B vitamins as regulators of phytoplankton dynamics. EOS 87, 593-596.

Partensky, F., Hess, W. R., and Vaulot, D. (1999). Prochlorococcus, a marine photosynthetic prokaryote of global significance. Microbiol. Mol. Biol. Rev. 63, 106-127.

Pinto, E., Nieuwerburgh, L., Barros, M., Pedersen, M., Colepicolo, P. and Snoeijs, P. (2003). Density dependant patterns in thiamine and pigment production in the diatom Nitzschia microcephala. Phytochemistry 63, 155-163.

Provasoli, L. (1963). "Organic regulation of phytoplankton fertility," in The Sea, ed M. N. Hill (New York, NY: Interscience), 165-219.

Provasoli, L., and Carlucci, A. F. (1974). "Vitamins and growth regulators," in Algal Physiology and Biochemistry, ed W. P. D Stewart (Oxford: Blackwell), 741-787.

Ransom Hardison, D., Sunda, W. G., Litaker, R. W., Shea, D., and Tester, R. A. (2012). Nitrogen limitation increases brevetoxins in Karenia brevis: implications for bloom toxicity. J. Phycol. 48, 844-858.

Rapala-Kozik, M., Wolak, N., Kujda, M., and Banas, A. K. (2012). Upregulation of thiamine biosynthesis in A. thaliana seedlings under salt and osmotic stress conditions is mediated by abscisic acid at the early stages of this stress response. BMC Plant Biol. 12:2. doi: 10.1186/ 1471-2229-12-2 
Raux, E., Schubert, H. L., and Warren, M. J. (2000). Biosynthesis of cobalamin (vitamin $\mathrm{B}_{12}$ ): a bacterial conundrum. Cell. Mol. Life Sci. 57, 1880-1893.

Rodionov, D. A., Vitreschak, A. G., Mironov, A. A., and Gelfand, M. S. (2002). Comparative genomics of thiamine biosyntheisis in prokaryotes. J. Biol. Chem. 277, 48949-48959.

Rodionov, D. A., Vitreschak, A. G., Mironov, A. A., and Gelfand, M. S. (2003). Comparative genomics of the Vitamin $\mathrm{B}_{12}$ metabolism and regulation in prokaryotes. J. Biol. Chem. 278, 41148-41159.

Roth, J. R., Lawrence, J. G., and Bobik, T. A. (1996). Cobalamin (coenzyme $\mathrm{B}_{12}$ ): synthesis and biological significance. Annu. Rev. Microbiol. 50, 137-181.

Saito, M. A., Goepfert, T. J., and Ritt, J. T. (2008). Some thoughts on the concept of colimitation: three definitions and the importance of bioavailability. Limnol. Oceanogr. 53, 276-290.

Sañudo-Wilhelmy, S. A., Cutter, L., Durazo, R., Smail, E., GomezConsarnau, L., Webb, E. A., et al. (2012). Multiple B-vitamin deficiency in large areas of the coastal ocean. Proc. Natl. Acad. Sci. U.S.A. 109, 14041-14045.

Sañudo-Wilhelmy, S. A., Okbamichael, M., Gobler, C. J., and Taylor, G. T. (2006). Regulation of phytoplankton dynamics by vitamin B12. Geophys. Res. Lett. 33, LO4604.

Scheffel, A., Poulsen, N., Shian, S., and Kroger, N. (2011). Nanopatterned protein microrings from a diatom that direct silica morphognesis.
Proc. Natl. Acad. Sci. U.S.A. 108, 3175-3180.

Schrauzer, G. N., and Deutsch, E. (1969). Reactions of cobalt(I) supernucleophiles. the alkylation of vitamin B12s, cobaloximes (I), and related compounds. J. Am. Chem. Soc. 91, 3341-3350.

Scott, J. M., and Weir, D. G. (1981). The methyl folate trap: a physiological response in man to prevent methyl group deficiency in kwashiorkor (methionine deficiency) and an explanation for folic-acid-induced exacerbation of subacute combined degeneration in pernicious anaemia. Lancet 318, 337-340.

Shihira, I., and Krauss, R. W. (1965). Chlorella: Physiology and Taxonomy of 41 Isolates. College Park, PA: University of Maryland Press.

Stefels, J. P. (2000). Physiological aspects of the production and conversion of DMSP in marine algae and higher plants. J. Sea Res. 43, 183-197.

Sunda, W., Kieber, D. J., Kiene, R. P., and Huntsman, S. (2002). An antioxidant function for DMSP and DMS in marine algae. Nature 418, 317-320.

Sunda, W. G., Hardison, R., Kiene, R., Bucciarelli, E., and Harada, H. (2007). The effect of nitrogen limitation on cellular DMSP and DMS release in marine phytopankton: climate feedback implications. Aquat. Sci. 69, 341-351.

Swift, D. (1981). Vitamin levels in the Gulf of Maine and ecological significance of vitamin B12 there. J. Mar. Res. 39, 375-403.

Swift, D. G., and Guillard, R. R. (1978). Unexpected response to vitamin B12 of dominant centric diatoms from the spring bloom in the Gulf of Maine. J. Phycol. 14, 377-386.

Swift, D. G., and Taylor, W. R. (1972). Growth of vitamin B12 - limited cultures: Thalassiosira pseudonana, Monochyrsis lutheri, and Isochrysis galbana. J. Phycol. 10, 385-391.

Takahashi, H., Kopriva, S., Giordano, M., Saito, K., and Hell, R. (2011). Sulfur assimilarion in photosynthetic organisms: molecular function and regulation transporters and assimilatory proteins. Annu. Rev. Plant Biol. 62, 157-184.

Tang, Y. Z., Koch, F., and Gobler, C. J. (2010). Most harmful algal bloom species are vita$\min \quad B 1$ and $B_{12}$ auxotrophs. Proc. Natl. Acad. Sci. U.S.A. 107, 20756-20761.

Teeling, H., Fuchs, B. M., Becher, D., Klockow, C., Gardebrecht, A., Bennke, C. M., et al. (2012). Substrate-controlled succession of marine bacterioplankton populations induced by a phytoplankton bloom. Science 336, 608-611.

Toulza, E., Shin, M. S., Blanc, G., Audic, S., Laabir, M., Collos, Y., et al. (2010). Gene expression in proliferating cells of the dinoflagellate Alexandrium catenella. Appl. Environ. Microbiol. 76, 4521-4529.

Webb, M., Marquet, A., Mendel, R., Rebeille, F., and Smith, A. (2007). Elucidating biosynthetic pathways for vitamins and cofactors. Nat. Prod. Rep. 24, 988-1008.

Worden, A. Z., Lee, J. H., Mock, T., Rouzé, P., Simmons, M. P., Aerts, A. L., et al. (2009). Green evolution and dynamic adaptations revealed by genomes of the marine picoeukaryotes Micromonas. Science 324, 268-274.

Zehr, J. P., and Ward, B. B. (2002) Nitrogen cycling in the ocean: new perspectives on processes and paradigms. Appl. Environ. Microbiol. 68, 1015-1024.

Zhang, Y., Rodionov, D. A., Gelfand, M. S., and Gladyshev, V. N. (2009). Comparative genomics analysis of nickel, cobalt, and vitamin $\mathrm{B}_{12}$ utilization. BMC Genomics 10:78. doi: 10.1186/1471-2164-10-78

Conflict of Interest Statement: The authors declare that the research was conducted in the absence of any commercial or financial relationships that could be construed as a potential conflict of interest.

Received: 07 August 2012; paper pending published: 12 September 2012; accepted: 02 October 2012; published online: 19 October 2012.

Citation: Bertrand EM and Allen $A E$ (2012) Influence of vitamin B auxotrophy on nitrogen metabolism in eukaryotic phytoplankton. Front. Microbio. 3:375. doi: 10.3389/fmicb.2012.00375

This article was submitted to Frontiers in Aquatic Microbiology, a specialty of Frontiers in Microbiology. Copyright (c) 2012 Bertrand and Allen. This is an open-access article distributed under the terms of the Creative Commons Attribution License, which permits use, distribution and reproduction in other forums, provided the original authors and source are credited and subject to any copyright notices concerning any third-party graphics etc. 